\title{
Editorial
}

\section{Global Scholarship}

Between one thing and another, globalization is a lot on my mind these days.

The primary reason hits close to home-my 16-year-old daughter is going to be heading off on student cultural exchange in a few months-to Thailand. We are all very excited that she has this opportunity that will broaden her understanding of the world in a way that school can't approach. I will admit that it has been difficult to reconcile this optimism with my day job working with the Department of International Affairs where I help students and faculty do research on such topics as nuclear deterrence, civil unrest, food insecurity and human trafficking among others. My daughter going to Thailand has forced me to face some of the biases in that international affairs/security lens-particularly as I consider "safe places," Her initial choices for student exchange were in a European country and a developed Asian country, considered one of the safest in the world. Learning that she was selected to go to Thailand was unexpected to say the least and we have had to try to balance the fact that Thailand is Tier 1 on the State Department's foreign travel list ("Exercise normal precautions in Thailand. Some areas have increased risk...due to civil unrest $\left.{ }^{\prime \prime}\right)$ with the goal of cultural exchange and a once in a lifetime experience.

This situation has reminded me of the importance of building global communities and brought home that it is necessary to challenge the biases and assumptions that are present in our lives. This was reinforced by the recent release of a new book by ACRL The Globalized Library: American Academic Libraries and International Students, Collections, and Practices which "features practitioners from across North American detailing new approaches, technologies, and pedagogies for welcoming and educating diverse student bodies and supporting faculty research and teaching worldwide." ${ }^{2}$ It is a useful examination of how libraries engage with an international community in the United States.

It is also beneficial to engage with international communities where they are and for libraries to develop the global community wherever they are. A few years ago, I attended IFLA for the first time and was struck by how access was considered from a different perspective; specifically, that freedom of speech and freedom of information could not be taken for granted and that approaches to innovations and services could not necessarily be dependent on highdollar systems. It brought home how many advantages academic libraries in the US have. IFLA "It is the global voice of the library and information profession" and their Strategic Directions are focused on initiatives such as:

- "Promoting libraries within the United Nations 2030 Agenda for Sustainable Development"

- "Promoting reading and literacy as an essential requirement for active participation in society"

- "Influencing the future of Internet governance"

- "Safeguarding documentary cultural heritage through Disaster Risk Reduction"3 
These are just a few initiatives but they are representative of the level of policy engagement and social responsibility that permeate IFLA's activities. It was both eye-opening and inspiring.

It has also prompted me to reflect on the representation in the journal and on the growing number of submissions we are seeing from foreign countries-which I am glad to see. The ACRL Board of Directors has made diversity and inclusion a priority over the past few years in an effort to be a model for academic librarians and academic libraries both. While academic libraries have focused on ways to enhance the global literacy of the students they serve as well as meet the needs of international students, providing diverse perspectives from various states in the global community is also important.

$C \mathcal{E} R L$ has seen an increase in the submissions from the international community. Below is a listing of some of the submission authors since 2017 (some authors did not put their addresses on their accounts):

$\begin{array}{llllll}\text { Anguilla } & \text { Chile } & \text { Great Britain } & \text { Iraq } & \text { Poland } & \text { Sweden } \\ \text { Australia } & \text { China } & \text { Hong Kong } & \text { Italy } & \text { Romania } & \text { Turkey } \\ \text { Austria } & \text { Denmark } & \text { Iceland } & \text { Korea } & \text { Saint Martin } & \\ \text { Belgium } & \text { Finland } & \text { India } & \text { Netherlands } & \text { Saudi Arabia } & \\ \text { Brazil } & \text { France } & \text { Indonesia } & \text { Nigeria } & \text { Spain } & \\ \text { Canada } & \text { Germany } & \text { Iran } & \text { Pakistan } & \text { Sri Lanka } & \end{array}$

The representation of authors and peer reviewers was previously discussed in the July 2016 editorial $^{4}$ which included a chart looking at submissions by country between 2012 and 2016. It is interesting to note the changes in the journal submissions in just that short time.

This is not to say that they have all been published. College $\mathcal{E}$ Research Libraries always receives a lot of submissions that are more case studies or local best practices. They may duplicate a previous study in a different geography; this is not sufficient for acceptance in $C \mathcal{E} R L$ although CERL News may be an option for the more innovative of these studies.

I expect that readers will have noticed the increased number of articles from an international context. This is deliberate-in some cases, the context provides original findings and has implications that broaden previous studies. Referring back to my work with students in International Affairs and Political Science, one of the most important topics we discuss is the authority of the sources, both primary and secondary, and the perspective of the source including slant or bias and the relevance to the topic. We acknowledge that the resources, of necessity for this audience, may be English language - but the representation of other cultures and world views is critical for understanding and broadening knowledge.

This is no less true in librarianship - the scholarly dialogue is global.

\section{Notes}

1. "Thailand Travel Advisory," U.S. Department Of State-Bureau Of Consular Affairs, updated January 29, 2019, https:/travel.state.gov/content/travel/en/traveladvisories/traveladvisories/thailand-travel-advisory.html [accessed 12 February 2019].

2. "ACRL releases The Globalized Library: American Academic Libraries and International Students, Collections, and Practices," American Library Association, updated January 15, 2019, http://www.ala.org/news/membernews/2019/01/acrl-releases-globalized-library-american-academic-libraries-and-international [accessed 12 February 2019].

3. "IFLA Strategic Directions and Key Initiatives," The International Federation of Library Associations and Institutions (IFLA), updated December 10, 2018, https://www.ifla.org/node/10071 [accessed 12 February 2019].

4. Wendi Arant Kaspar, "An Introduction," College \& Research Libraries 77, no. 4, (July 2016): 406-09, available at: https://crl.acrl.org/index.php/crl/article/view/16522 [accessed 12 February 2019]. 